\title{
APPLICATIONS OF THE HELLENIC NATURAL ZEOLITE (HENAZE) AND SPECIFICATIONS OF ZEOLITIC TUFFS
}

Filippidis A.

Aristotle University of Thessaloniki, Faculty of Sciences, School of Geology, Department of Mineralogy-Petrology-Economic Geology, 54124 Thessaloniki, Greece, anestis@geo.auth.gr

\begin{abstract}
The Hellenic Natural Zeolite (HENAZE) is free of fibres and contains $89 w t \%$ clinoptilolite, $3 \mathrm{wt} \%$ mica + clay minerals, $3 \mathrm{wt} \%$ quartz, $2 \mathrm{wt} \%$ cristobalie \pm tridymite and 3 wt\% feldspars. HENAZE do not meet the requirements of the EU Regulation No 651/2013, and thus cannot be used as feed additive for all animal species and consequently as nutrition supplement, since it contains $3 \mathrm{wt} \%$ quartz. HENAZE is suitable for use as soil conditioner, since the concentration of trace elements are lower than the maximum allowable concentrations in agricultural soils (EU Directive 278/1986). HENAZE as soil conditioner: a) improved the $p H$ of acid soils by $47-55 \%, b)$ reduced the leaching of metals by 33-71\% from contaminated soils, c) reduced the $\mathrm{Hg}$ concentration by $47-78 \%$ in shoots and roots of plants, $d$ ) increased the production of agricultural products by $17-95 \%, e$ ) decreased the plantlosses in new vineyard by $12 \%$ and f) improved the quality of tomato by $4-46 \%$. The HENAZE neutralized sewage-sludge (producing zeo-sewage-sludge), industrialsludge (producing zeo-sludge), battery solid waste and mine solid wastes (minetailings). The zeo-sewage-sludge and zeo-sludge are odorless, cohesive and suitable for safe deposition. The treatment of sewage-sludge and industrial-sludge with the HENAZE, reduced the leaching of metals by $91-100 \%$ and of $\mathrm{NO}_{3}-$ by $81-82 \%$. Depending on the trace element contents, the zeo-sewage-sludge can be used as soil conditioner. HENAZE sorbed-removed 37-92\% of metals, radionuclides and cyanobacteria from their solutions and waters. The treatment of wastewaters (urban, dyeing-industry, industrial area and tanning-work) with HENAZE, improved the quality characteristics by 48-99\%. The HENAZE reduced the $\mathrm{NO}_{3}{ }^{-}$load by $54-94 \%$ in groundwater, nitrate-solutions, industrial and urban wastewaters. Considering, the European, Global and Greek legislation, the mineralogical, chemical, morphological and radiological characteristics, as well as the leachability and bioavailability of chemical elements, the specifications for the different applications-uses of the zeolitic tuffs are defined.
\end{abstract}

Keywords: Clinoptilolite, feed additive, nutrition supplement, soil conditioner.

\section{Пєрí $\eta \psi \eta$}

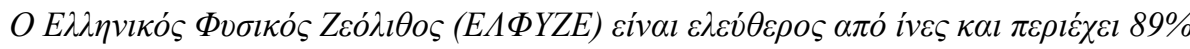

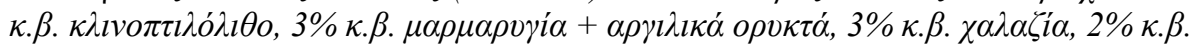

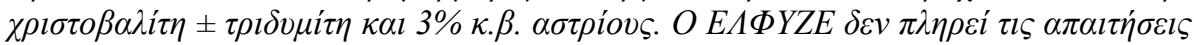

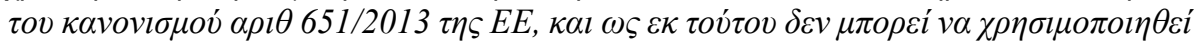

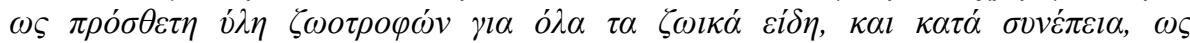

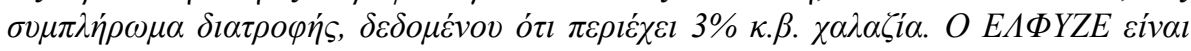

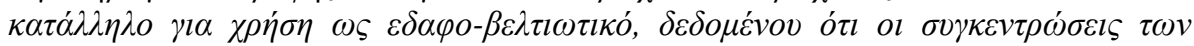

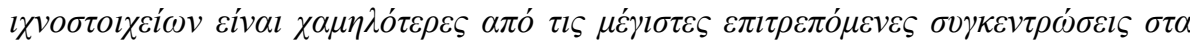




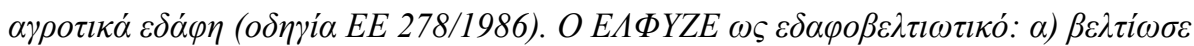

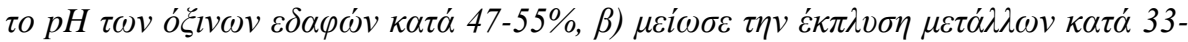

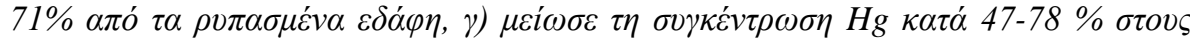

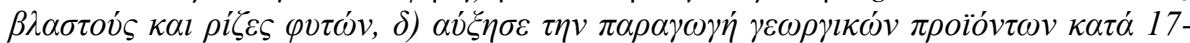

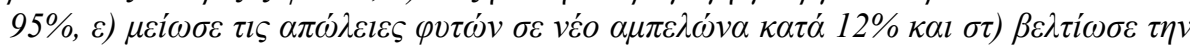

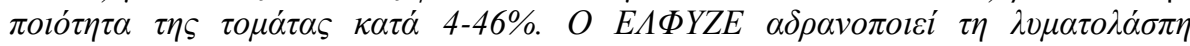

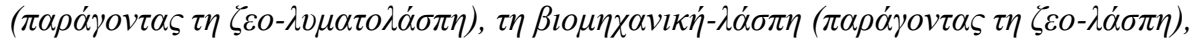

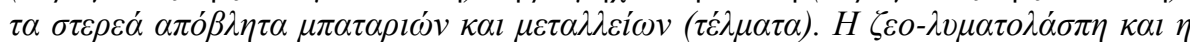

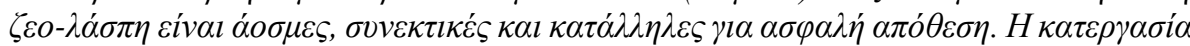

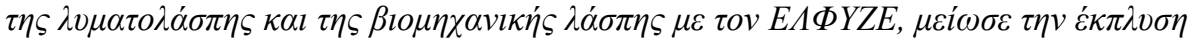

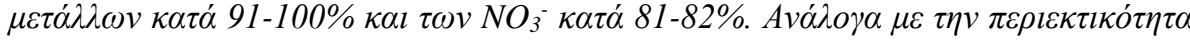

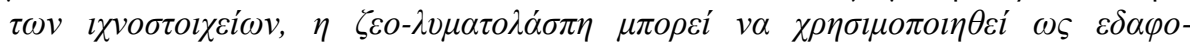

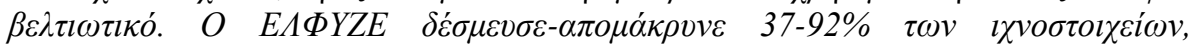

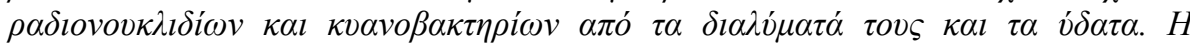

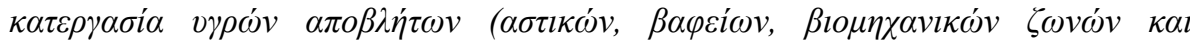

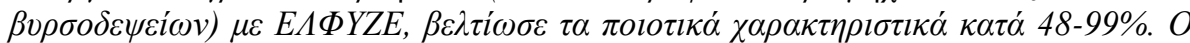

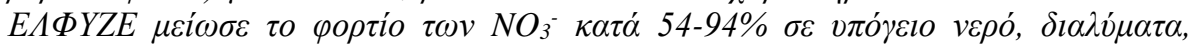

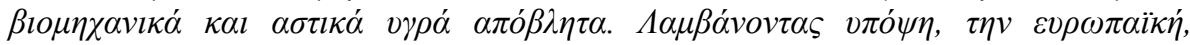

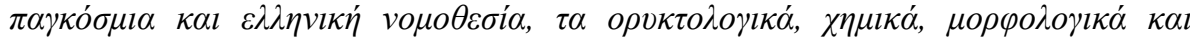

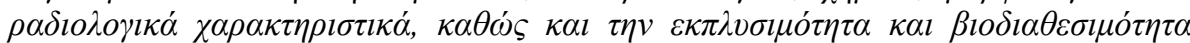

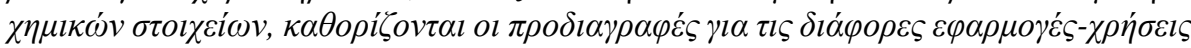

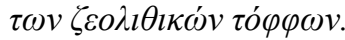

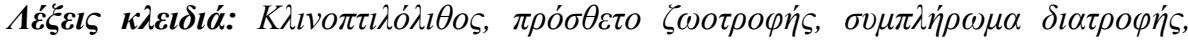
$\varepsilon \delta \alpha \varphi \circ \beta \varepsilon \lambda \tau \iota \omega \tau \iota \kappa o ́$.

\section{Introduction}

The Zeolitic volcaniclastic rock deposit corresponds to a rock which contains high amounts of one or more from the different $(>65)$ phases of zeolites. The zeolite with the numerous applications is the HEU-type zeolite (clinoptilolite-heulandite) that shows tabular crystals and contains micro/nanopores in a framework of channels with 10- and 8-member rings, in dimensions of $7.5 \times 3.1 \AA$, 4.6x3.6 $\AA$ and $4.7 \times 2.8 \AA$. Only clinoptilolite of sedimentary origin with $\geq 80 \mathrm{wt} \%$ clinoptilolite, $\leq 20 \mathrm{wt} \%$ clay minerals, free of fibres and quartz, can be used as feed additive for all animal species (EU Regulation No 651/2013) and consequently as nutrition supplement. In humans and animals, inhaled or injected or swallowed, fibrous zeolites (erionite, mordenite, etc), as well as the $\mathrm{SiO}_{2}$ minerals (quartz, cristobalite, tridymite), are toxic, carcinogenic and highly pathogenic (e.g., Davis, 1993; Driscoll, 1993; Saffiotti et al., 1993). The Maximum Allowable Concentrations (MAC) of the trace elements in soils, are specified as limit values for concentrations of heavy metals in soil, in the ANNEX IA of the EU Directive 278/1986.

In the Ntrista stream location (concession of GEO-VET N. Alexandridis \& Co O.E.) of Petrota village has been identified a clinoptilolite deposit, specific layers of zeolitic tuffs (Filippidis and Kantiranis, 2002; Filippidis, 2005), named the Hellenic Natural Zeolite (HENAZE) (e.g., Filippidis et al., 2007, 2008a,b,d-g, 2009a,b, 2010a,b, 2011 a-c, 2014, 2015c; Filippidis, 2010a,b; Vogiatzis, et al. 2012). The aim of the present study is to investigate the quality characteristics and applications of the HENAZE, to evaluate its potential use as feed additive (in accordance with the EU Regulation No 651/2013), as nutrition supplement and as soil conditioner in agriculture (in accordance with the EU Directive 278/1986) and define the specifications of the zeolitic tuffs for the different uses.

\section{Materials, Methods and Quality characteristics}

The Hellenic Natural Zeolite (HENAZE) samples was supplied by GEO-VET N. Alexandridis \& Co O.E. Different granulates $(8-4,4-1.5,<1.5,<0.5 \mathrm{~mm})$ of the HENAZE were used in different 
applications. The petrographic investigation of the HENAZE was performed on thin and polished thin sections. The combined methods of SEM-EDS (microanalyses), thermal treatment at 450o C for 8 hours and X-Ray Diffraction (XRD), revealed that the HEU-type zeolite in the HENAZE, in two samples presents characteristics of group I zeolite (clinoptilolite) and in one sample of group II (intermediate heulandite). The morphology and the microanalyses of the minerals were studied by Scanning Electron Microscopy-Energy Dispersive Spectroscopy (SEM-EDS) with Link-AN 10000 EDS system. The microscopic examination of the thin sections revealed a fine-grained vitroclastic texture containing shards (0.1-2.0 mm in size), angular to subangular quartz and feldspars and tabular mica crystals. The lath-tabular shaped crystals of clinoptilolite $(\sim 5-50 \mu \mathrm{m}$ in size) are abundant as interstitial cements and as polycrystallites in the shards. The peripheral zone of the shards is a very thin rim of clay minerals. The chemical formulae of the minerals are: clinoptilolite $\mathrm{Ca} 1.8 \mathrm{~K} 1.1 \mathrm{Mg} 0.7 \mathrm{Na} 0.5 \mathrm{Al} 6.4 \mathrm{Si} 29.6 \mathrm{O} 72.21 \mathrm{H} 2 \mathrm{O}$, $\mathrm{Mg} 1.4 \mathrm{Fe} 1.1 \mathrm{~K} 0.8 \mathrm{Na} 0.1 \mathrm{Mn} 0.1 \mathrm{Ti} 0.3 \mathrm{~A} 11.4 \mathrm{Si} 2.6$

$$
\mathrm{O} 10(\mathrm{OH}) 2, \quad \text { clay }
$$
$\mathrm{Fe} 1.0 \mathrm{~K} 0.9 \mathrm{Mg} 0.4 \mathrm{Ca} 0.2 \mathrm{Al} 2.4(\mathrm{Al} 0.2 \mathrm{Si} 7.8) \mathrm{O} 20(\mathrm{OH}) 4 \cdot 2.9 \mathrm{H} 2 \mathrm{O}, \quad$ alkali-feldspar $\mathrm{K} 0.6 \mathrm{Na} 0.4 \mathrm{All} .0 \mathrm{Si} 3.0 \mathrm{O}$, plagioclase (andesine) $\mathrm{Na0} 5 \mathrm{Ca0} .5 \mathrm{Al1} .4 \mathrm{Si} 2.6 \mathrm{O}$ and quartz, cristoba tridymite $\mathrm{SiO} 2$. Cell parameter refinements were performed with XRD-data, using the 30 strongest and well defined reflections. The cell dimensions of clinoptilolite (monoclinic, $\mathrm{C} 2 / \mathrm{m}$ ) are: $\mathrm{a}=17.663$ $\AA, \mathrm{b}=17.917 \AA, \mathrm{c}=7.406 \AA, \mathrm{V}=2099.64 \AA 3$ and $\beta=116038$ '.

The mineralogical composition of six samples of HENAZE were determined by the X-Ray Diffraction (XRD) method. The semi-quantitative mineralogical composition was measured, using the intensity (counts) of certain reflections, the density and the mass absorption coefficient of the identified minerals for $\mathrm{CuK} \alpha$ radiation, the software MAUD-Material Analysis Using Diffraction with the RIETVELD method. Clay mineralogy was identified from air-dried, glycolated and heattreated oriented samples. The ammonia ion exchange capacity (sorption ability) was determined according to the Ammonium Acetate Saturation (AMAS) method (Filippidis and Kantiranis, 2007). On average, the HENAZE shows sorption ability of $187 \mathrm{meq} / 100 \mathrm{~g}$ and contains $89 \mathrm{wt} \%$ clinoptilolite (Table 1).

Table 1 - Mineralogical composition (wt\%) of the Hellenic Natural Zeolite (HENAZE).

\begin{tabular}{|lcccccc|c|}
\hline Samples & EN & EN & EN & EN & EN & EN & Average \\
& $\mathbf{1}$ & $\mathbf{2}$ & $\mathbf{3}$ & $\mathbf{4}$ & $\mathbf{5}$ & $\mathbf{6}$ & (range) \\
\hline Clinoptilolite & 83 & 89 & 89 & 89 & 90 & 91 & $89(83-91)$ \\
\hline Mica + Clay minerals (smectite, illite, celadonite) & 4 & 4 & 3 & 3 & 2 & 2 & $3(2-4)$ \\
\hline Quartz & 4 & 2 & 3 & 3 & 4 & 3 & $3(2-4)$ \\
\hline Cristobalite + tridymite & 2 & 2 & 1 & 3 & 2 & 2 & $2(1-3)$ \\
\hline Feldspars (alkali-feldspar + plagioclase) & 7 & 3 & 4 & 2 & 2 & 2 & $3(2-7)$ \\
\hline Total & 100 & 100 & 100 & 100 & 100 & 100 & 100 \\
\hline Sorption ability (meq/100g) & 175 & 186 & 187 & 190 & 191 & 191 & $187(175-191)$ \\
\hline
\end{tabular}

The chemical composition (major and trace elements) of the HENAZE (Tables 2 and 3) was determined by FUS-ICP (Fusion-Inductively Coupled Plasma), FUS-MS (Fusion-Mass Spectrometry), TD-ICP (Total Digestion-Inductively Coupled Plasma), INAA (Instrumental Neutron Activation Analysis) and FA (Fire Assay). The contents of the trace elements $\mathrm{Cd}, \mathrm{Cr}, \mathrm{Cu}, \mathrm{Hg}, \mathrm{Ni}, \mathrm{Pb}$ and $\mathrm{Zn}$ are $\leq 46 \mathrm{ppm}$, all values are lower than the limit values in soil (EU Directive 278/1986) (Table 2).

The leachability of the main exchangeable cations from the HENAZE is very low: $\mathrm{Mg}(0 \%), \mathrm{Ca}$ $(0 \%), \mathrm{K}(0.0020 \%)$ and $\mathrm{Na}(0.0467 \%)$. The agricultural applications were applied in fields and greenhouses, always compared to a control. The wastewaters were treated in batch-type experiments, under continuous stirring and at the final stage, coagulants were added. 
Table 2 - Chemical composition of the Hellenic Natural Zeolite (HENAZE).

\begin{tabular}{|c|c|c|c|c|c|c|}
\hline \multicolumn{6}{|c|}{ HENAZE } & \multirow{2}{*}{$\begin{array}{c}\text { Limit Values in Soil* } \\
1-3 \mathrm{ppm}\end{array}$} \\
\hline $\mathrm{SiO}_{2} \mathrm{wt} \%$ & 66.79 & $\mathrm{CaO}$ wt $\%$ & 2.71 & $\mathrm{Cd}$ & $<0.5 \mathrm{ppm}$ & \\
\hline $\mathrm{TiO}_{2}$ & 0.17 & $\mathrm{Na}_{2} \mathrm{O}$ & 1.23 & $\mathrm{Cr}$ & $23 \mathrm{ppm}$ & $50-150 \mathrm{ppm}$ \\
\hline $\mathrm{Al}_{2} \mathrm{O}_{3}$ & 12.07 & $\mathrm{~K}_{2} \mathrm{O}$ & 2.37 & $\mathrm{Cu}$ & $2 \mathrm{ppm}$ & $50-140 \mathrm{ppm}$ \\
\hline $\mathrm{Fe}_{2} \mathrm{O}_{3 \mathrm{t}}$ & 1.22 & $\mathrm{P}_{2} \mathrm{O}_{5}$ & 0.02 & $\mathrm{Hg}$ & $0.006 \mathrm{ppm}$ & $1-1.5 \mathrm{ppm}$ \\
\hline $\mathrm{MnO}$ & 0.03 & LOI & 12.39 & $\mathrm{Ni}$ & $4 \mathrm{ppm}$ & $30-75 \mathrm{ppm}$ \\
\hline $\mathrm{MgO}$ & 0.92 & Total & 99.92 & $\mathrm{~Pb}$ & $41 \mathrm{ppm}$ & $50-300 \mathrm{ppm}$ \\
\hline \multicolumn{4}{|c|}{ *) EU Directive 86/278/EEC 1986} & $\mathrm{Zn}$ & $46 \mathrm{ppm}$ & $150-300 \mathrm{ppm}$ \\
\hline
\end{tabular}

Table 3 - Trace element contents of the Hellenic Natural Zeolite (HENAZE).

\begin{tabular}{|c|c|c|c|c|c|c|c|}
\hline$(\mathrm{ppm})$ & Method & Det. limit & HENAZE & $(\mathrm{ppm})$ & Method & Det. limit & HENAZE \\
\hline $\mathrm{Ag}$ & FUS-MS & 0.5 & $<0.5$ & Mo & FUS-MS & 2 & $<2$ \\
\hline As & INAA & 2 & 4 & $\mathrm{Nb}$ & FUS-MS & 0.2 & 15.0 \\
\hline $\mathrm{Au}$ & INAA & 0.005 & $<0.005$ & $\mathrm{Nd}$ & FUS-MS & 0.1 & 19.9 \\
\hline $\mathrm{Ba}$ & FUS-ICP & 3 & 172 & $\mathrm{Ni}$ & TD-ICP & 1 & 4 \\
\hline $\mathrm{Be}$ & FUS-ICP & 1 & 6 & $\mathrm{~Pb}$ & FUS-MS & 5 & 41 \\
\hline $\mathrm{Bi}$ & FUS-MS & 0.1 & 0.2 & $\operatorname{Pr}$ & FUS-MS & 0.01 & 7.08 \\
\hline $\mathrm{Br}$ & INAA & 1 & $<1$ & $\mathrm{Rb}$ & FUS-MS & 1 & 150 \\
\hline $\mathrm{Cd}$ & TD-ICP & 0.5 & $<0.5$ & $\mathrm{Sb}$ & FUS-MS & 0.2 & 0.2 \\
\hline $\mathrm{Ce}$ & FUS-MS & 0.1 & 64.4 & $\mathrm{Sc}$ & INAA & 0.1 & 3.0 \\
\hline $\mathrm{Co}$ & FUS-MS & 1 & 8 & $\mathrm{Se}$ & INAA & 3 & $<3$ \\
\hline $\mathrm{Cr}$ & INAA & 1 & 23 & $\mathrm{Sm}$ & FUS-MS & 0.01 & 3.52 \\
\hline Cs & FUS-MS & 0.1 & 8.9 & $\mathrm{Sn}$ & FUS-MS & 1 & 4 \\
\hline $\mathrm{Cu}$ & TD-ICP & 1 & 2 & $\mathrm{Sr}$ & FUS-ICP & 2 & 1104 \\
\hline Dy & FUS-MS & 0.01 & 3.44 & $\mathrm{Ta}$ & FUS-MS & 0.01 & 1.13 \\
\hline $\mathrm{Er}$ & FUS-MS & 0.01 & 2.29 & $\mathrm{~Tb}$ & FUS-MS & 0.01 & 0.24 \\
\hline $\mathrm{Eu}$ & FUS-MS & 0.005 & 0.294 & $\mathrm{Th}$ & FUS-MS & 0.1 & 30.5 \\
\hline $\mathrm{Ga}$ & FUS-MS & 1 & 14 & $\mathrm{Tl}$ & FUS-MS & 0.05 & 1.29 \\
\hline $\mathrm{Gd}$ & FUS-MS & 0.01 & 3.12 & $\mathrm{Tm}$ & FUS-MS & 0.005 & 0.367 \\
\hline $\mathrm{Ge}$ & FUS-MS & 0.5 & 1.4 & $\mathrm{U}$ & FUS-MS & 0.01 & 8.56 \\
\hline Hf & FUS-MS & 0.1 & 4.3 & $\mathrm{~V}$ & FUS-ICP & 5 & 17 \\
\hline $\mathrm{Hg}$ & FA & 0.005 & 0.006 & $\mathrm{~W}$ & FUS-MS & 0.5 & 3.7 \\
\hline Ho & FUS-MS & 0.01 & 0.72 & $\mathrm{Y}$ & FUS-MS & 0.5 & 20.4 \\
\hline In & FUS-MS & 0.1 & $<0.1$ & $\mathrm{Yb}$ & FUS-MS & 0.01 & 2.52 \\
\hline $\mathrm{Ir}$ & INAA & 0.005 & $<0.005$ & $\mathrm{Zn}$ & TD-ICP & 1 & 46 \\
\hline $\mathrm{La}$ & FUS-MS & 0.1 & 37.1 & $\mathrm{Zr}$ & FUS-ICP & 2 & 137 \\
\hline $\mathrm{Lu}$ & FUS-MS & 0.002 & 0.409 & & & & \\
\hline
\end{tabular}

FUS-MS: Fusion Mass Spectrometry, FUS-ICP: Fusion Inductively Coupled Plasma, INAA: Instrumental Neutron Activation Analysis, TD-ICP: Total Digestion ICP, FA: Fire Assay 


\section{Agricultural, Industrial and Environmental Applications}

The Hellenic Natural Zeolite (HENAZE) as soil conditioner $(500 \mathrm{~kg} / \mathrm{acre})$ increased the initial $\mathrm{pH}$ (3.8-4.0) of soil to 5.6-6.0 after 16 days (improvement 47-50\%) and to 5.8-6.2 after 5 years (improvement $53-55 \%$ ). The use of HENAZE (500kg/acre) for the reclamation of contaminated soils reduced the seepage of $\mathrm{Cd}$ by $33 \%$, of $\mathrm{Cs}$ by $39 \%$, of $\mathrm{Pb}$ by $44 \%$, of $\mathrm{Zn}$ by $52 \%$ and of $\mathrm{Ni}$ by $60 \%$, also for the reclamation of mine land reduced the seepage of $\mathrm{Cd}$ by $43 \%$, of $\mathrm{Pb}$ by $52 \%$ and $\mathrm{Zn}$ by $71 \%$. The use of HENAZE $(600 \mathrm{~kg} / \mathrm{acre})$ reduced the $\mathrm{Hg}$ concentration in the trifolium by $77 \%$ in the shoots and $53 \%$ in the roots, while in the grass by $78 \%$ in the shoots and $47 \%$ in the roots. The HENAZE as soil conditioner improves the physicochemical and nutritious abilities of soils, reinforces the root-system of the plants, improves the quality of tomato by $4-46 \%$, decreases the plant-losses in new vineyard by $12 \%$ and increases the crops yield of agricultural products on average by $17-95 \%$ (Table 4 ).

Table 4 - Hellenic Natural Zeolite (HENAZE) (200-600 kg/acre) in agricultural soils.

\begin{tabular}{|lrrrr|c|}
\hline \multirow{2}{*}{ Product (area) } & \multicolumn{5}{c|}{ Production increase (\%) } \\
\cline { 2 - 7 } & $*$ & $* *$ & $* * *$ & This study & Average \\
\hline Barley, Gefyra (Thessaloniki) & - & - & - & 95 & 95 \\
\hline Potato, Gefyra & - & - & - & 94 & 94 \\
\hline Grapes, Ag. Athanasios (Thessaloniki) \& Gefyra & 73 & - & 48,66 & $25,65,99$ & $63(25-99)$ \\
\hline Maize & - & 50 & - & - & 50 \\
\hline Tomato, Aspro (Pella) \& Gefyra & 48 & 52 & - & $96,39,50,11$ & $49(11-96)$ \\
\hline Actinides, Livadochori (Serres) & 45 & - & - & - & 45 \\
\hline Wheat, Gefyra \& Livadochori & - & 29,57 & - & - & $43(29-57)$ \\
\hline Apples, Naousa (Imathia) & - & - & - & 33,37 & $35(33-37)$ \\
\hline Rice, Chalastra (Thessaloniki) & - & 34 & - & - & 34 \\
\hline Garlic, Gefyra & - & - & - & 33 & 33 \\
\hline Peaches, Naousa & - & - & - & 31,35 & $33(31-35)$ \\
\hline Cotton, Livadochori & 17 & - & - & - & 17 \\
\hline Carnation florescence increase, Sidirokastro (Serres) & 25 & - & - & 40 & $33(25-40)$ \\
\hline Decrease of plant-losses in new vineyard, Gefyra & - & - & - & 12 & 12 \\
\hline
\end{tabular}

*) Filippidis 2007, **) Filippidis et al. 2007, ***) Filippidis 2010a

The HENAZE effectively neutralize sewage-sludge, industrial area sludge, dangerous industrial solid wastes, such as battery solid waste, mine solid wastes (mine-tailings) and also the acid mine drainage. The HENAZE-treatment of the different solid wastes gave odorless and cohesive materials (zeo-sewage sludge, zeo-sludge, etc.) which are suitable for safe deposition since the fixation of dangerous species into the HENAZE, prevents the seepage by runoff or leaching, thus protecting the quality of soils, surface and groundwaters. The seepage of $\mathrm{Mn}, \mathrm{Ni}, \mathrm{Cr}$ and $\mathrm{NO}_{3}{ }^{-}$from sewagesludge was 7-100\%, while that from the zeo-sewage-sludge 0-19\%. The seepage of $\mathrm{Cr}$ and $\mathrm{NO}_{3}{ }^{-}$ from dyeing-industry-sludge was 40-100\%, while that from the zeo-sludge $0-18 \%$. The treatment of sewage-sludge and industrial sludge with HENAZE, reduced the nitrate leaching by $81 \%$ and $82 \%$, respectively (Table 5). The HENAZE in batch treatments, reduced the nitrate load by 55\% in groundwater (Lagkadas, Thessaloniki), by $57 \%$ in nitrate-solutions, by $54-70 \%$ in Sindos industrial area wastewaters (Thessaloniki), by $86-92 \%$ in Kilkis city urban wastewaters and by $94 \%$ in Thessaloniki dyeing industry wastewater (Table 6). 
Table 5 - Seepage of $\mathrm{NO}_{3}{ }^{-}$and metals from sewage-sludge(SS), zeo-sewage-sludge (ZSS), dyeing-industry-sludge (DIS) and zeo-sludge (ZS).

\begin{tabular}{|c|c|c|c|c|c|c|}
\hline *) & $\begin{array}{c}\mathrm{SS} \\
(\mathrm{mg} / \mathrm{kg}) \\
\end{array}$ & $\begin{array}{c}\text { Seepage water } \\
\text { from SS }(\mathrm{mg} / \mathrm{L})\end{array}$ & $\begin{array}{c}\text { Seepage } \\
(\%)\end{array}$ & $\begin{array}{c}\text { ZSS } \\
(\mathrm{mg} / \mathrm{kg})\end{array}$ & $\begin{array}{c}\text { Seepage water } \\
\text { from } \mathrm{ZSS}(\mathrm{mg} / \mathrm{L})\end{array}$ & $\begin{array}{c}\text { Seepage } \\
(\%)\end{array}$ \\
\hline $\mathrm{NO}_{3}{ }^{-}$ & 19.92 & 19.92 & 100 & 65.08 & 12.40 & 19 \\
\hline $\mathrm{Cr}$ & 0.08 & 0.02 & 25 & 0.10 & Bdl & 0 \\
\hline $\mathrm{Fe}$ & 0.18 & 0.04 & 22 & 0.22 & 0.02 & 9 \\
\hline $\mathrm{Ni}$ & 0.20 & 0.02 & 10 & 0.22 & Bdl & 0 \\
\hline $\mathrm{Mn}$ & 0.28 & 0.02 & 7 & 0.30 & Bdl & 0 \\
\hline$* *)$ & $\begin{array}{c}\text { DIS } \\
(\mathrm{mg} / \mathrm{kg})\end{array}$ & $\begin{array}{c}\text { Seepage water } \\
\text { from DIS }(\mathrm{mg} / \mathrm{L})\end{array}$ & $\begin{array}{c}\text { Seepage } \\
(\%)\end{array}$ & $\begin{array}{c}\mathrm{ZS} \\
(\mathrm{mg} / \mathrm{kg})\end{array}$ & $\begin{array}{c}\text { Seepage water } \\
\text { from ZS }(\mathrm{mg} / \mathrm{L})\end{array}$ & $\begin{array}{c}\text { Seepage } \\
(\%)\end{array}$ \\
\hline $\mathrm{NO}_{3}^{-}$ & 26.64 & 26.56 & 100 & 73.48 & 13.22 & 18 \\
\hline $\mathrm{Cr}$ & 0.05 & 0.02 & 40 & 0.06 & Bdl & 0 \\
\hline
\end{tabular}

*) Filippidis et al. 2015a, **) Filippidis et al. 2015b, Bdl: Below detection limit $(<0.02)$

Table 6 - Nitrate $\left(\mathrm{NO}_{3}{ }^{-}\right)$reduction by Hellenic Natural Zeolite (HENAZE).

\begin{tabular}{|lccc|}
\hline & $\begin{array}{c}\text { Initial concen- } \\
\text { tration }(\mathbf{m g} / \mathbf{L})\end{array}$ & $\begin{array}{c}\text { HENAZE } \\
\text { coagulants }(\mathbf{C})\end{array}$ & $\begin{array}{c}\text { Redu- } \\
\text { ction }(\boldsymbol{\%})\end{array}$ \\
\hline Groundwater (Lagkadas, Thessaloniki) $^{1}$ & 98 & HENAZE & 55 \\
\hline Nitrate-solutions $^{2}$ & 100 & HENAZE & 57 \\
\hline Sindos industrial area wastewater (Thessaloniki) $^{3}$ & 35 & HENAZE+C & $54-70$ \\
\hline Urban wastewater (Kilkis city) $^{4}$ & $42.30-75.70$ & HENAZE+C & $86-92$ \\
\hline Dyeing industry wastewater (Thessaloniki) $^{5}$ & 78.36 & HENAZE+C & 94 \\
\hline
\end{tabular}

$\left.{ }^{1}\right)$ Filippidis 2010a; Filippidis et al. 2006, ${ }^{2}$ ) Filippidis 2007, 2010a, ${ }^{3}$ ) Filippidis et al. 2011b,c, 2013, 2014, 2015c, ${ }^{4}$ ) Filippidis 2008, 2009, 2010a; Filippidis et al. 2008e, 2012, 2015a; Filippidis and Tsirambides 2012, ${ }^{5}$ ) Filippidis et al. 2015b.

The HENAZE is suitable for the sorption-removal of trace elements, radionuclides and cyanobacteria from their solutions and waters. Depending on the initial concentration, the HENAZE removed $37-87 \%$ of metals $(\mathrm{Cd}, \mathrm{Hg}, \mathrm{Ag})$ and $37-70 \%$ of radionuclides (Th, U, Cs) (Table 7). The sorption-removal of cyanobacteria from Lake water and culture by the HENAZE, reached values of $51-92 \%$ (Table 8).

Table 7 - Sorption (removal) of metals and radionuclides by Hellenic Natural Zeolite ( $1 \mathrm{~g}$ of HENAZE with grain-size $<0.5 \mathrm{~mm})$ from their solutions $(100 \mathrm{~mL})$.

\begin{tabular}{|ccccccc|}
\hline \multirow{2}{*}{ Initial concentration $(\mathbf{m g} / \mathbf{L})$} & $\mathbf{7 d}$ & $\mathbf{H g}$ & $\mathbf{A g}$ & $\mathbf{T h}$ & $\mathbf{U}$ & $\mathbf{C s}$ \\
\cline { 2 - 8 } & 37 & 70 & 84 & - & - & - \\
\hline 1000 & 56 & 82 & 87 & - & - & 60 \\
\hline 500 & - & - & - & 55 & 37 & 70 \\
\hline 100 & - & - & - & 58 & 40 & - \\
\hline 50 & & &
\end{tabular}


Table 8 - Cyanobacteria removal by Hellenic Natural Zeolite (HENAZE)*.

\begin{tabular}{|lcc|}
\hline & Cyanobacteria & Removal after HENAZE treatment (\%) \\
\hline \multirow{2}{*}{ Doirani Lake water } & Colonial Microcystis & 51 \\
\cline { 2 - 3 } & Filamentous & 75 \\
\hline Culture & Chroococcus & 91 and 92 \\
\hline Starting water: $70-200 \mathrm{~mL}$. HENAZE: $0.2-1.75 \mathrm{~g}$ (grain-size $<0.5,<1.5 \mathrm{~mm}$ ). Contact time: $60 \mathrm{~min}$ \\
\hline
\end{tabular}

*) Filippidis et al. 2010a, 2011a

The treatment of wastewaters (urban, textile industry, industrial area and tanning-work) with HENAZE and coagulants, resulted to production of clear water, free of odors, control the $\mathrm{pH}$ to neutral and improved the quality characteristics (on average) by 48-99\% (Tables 9 and 10). All values of the clear water quality parameters, after repeated treatments, can be within the required limits for disposition as downstream, irrigation, swimming and fish waters.

Table 9 - Purification of urban (U) and dyeing industry (DI) wastewaters by HENAZE and coagulants in batch-type experiments. Starting wastewater: $300 \mathrm{~mL}$. Average (range).

\begin{tabular}{|lcc|}
\hline & Improvement in U* (\%) & Improvement in DI** (\%) \\
\hline $\mathrm{pH}$ & $11(7-18)$ & $7(5-9)$ \\
\hline Color & $93(88-97)$ & 97 \\
\hline Suspended particles & $94(87-98)$ & $92(91-93)$ \\
\hline Chemical Oxygen Demand (COD) & $94(89-97)$ & $90(74-95)$ \\
\hline $\mathrm{P}_{2} \mathrm{O}_{5}$ & $97(91-99)$ & 98 \\
\hline $\mathrm{NH}_{4}$ & $98(97-99)$ & 98 \\
\hline $\mathrm{NO}_{3}{ }^{-}$ & $90(86-92)$ & 94 \\
\hline $\mathrm{Cr}^{-}$ & $86(83-90)$ & 75 \\
\hline $\mathrm{HENAZE}\left(6-7.7 * \mathrm{~g}, 10-12.5^{* *} \mathrm{~g}\right)$, Grain-size $(<0.5,<1.5 \mathrm{~mm})$, Stirring time $(2-60 * \mathrm{~min}, 2 * * \min )$ \\
\hline
\end{tabular}

*) Filippidis et al. 2008a-f, 2009a,b, 2010b, 2012, 2015a; Filippidis 2010b, 2013

**) Filippidis et al. 2008d,e,g, 2015b; Filippidis 2013

Table 10 - Purification of industrial area (I) and tanning-work (T) wastewaters by HENAZE and coagulants in batch-type experiments. Starting wastewater: $300 \mathrm{~mL}$. Average (range).

\begin{tabular}{|c|c|c|c|}
\hline \multicolumn{2}{|c|}{ Improvement in I* (\%) } & \multicolumn{2}{|c|}{ Improvement in $\mathrm{T}^{* *}(\%)$} \\
\hline $\mathrm{pH}$ & $5(4-6)$ & $\mathrm{pH}$ & 18 \\
\hline Color & 93 & Color & 98 \\
\hline Chemical Oxygen Demand & $74(69-77)$ & Suspended particles & 99 \\
\hline $\mathrm{P}_{2} \mathrm{O}_{5}$ & 97 & $\mathrm{P}_{2} \mathrm{O}_{5}$ & 99 \\
\hline $\mathrm{NO}_{3}^{-}$ & $60(54-70)$ & \multirow{3}{*}{\multicolumn{2}{|c|}{$\begin{array}{l}\text { HENAZE }\left(0.1-6.4^{*} \mathrm{~g}, 7.5^{* *} \mathrm{~g}\right) \\
\text { Grain-size }\left(<0.5^{*} \mathrm{~mm},<1.5^{* *} \mathrm{~mm}\right) \\
\text { Stirring time }\left(3^{*} \mathrm{~min}, 2^{* *} \mathrm{~min}\right)\end{array}$}} \\
\hline $\mathrm{Cr}$ & $85(77-88)$ & & \\
\hline $\mathrm{Pb}$ & $48(33-50)$ & & \\
\hline
\end{tabular}

*) Filippidis et al. 2011b,c, 2013, 2014, 2015c, **) Filippidis et al. 2008a; Filippidis 2013

Aquaculture: Cleaning the water and reducing ammonia by $90 \%$ by crossing three (3) sequential filters of HENAZE (grain size 1-8 mm). Air purification in fish feed plant: The strong odor reduction was achieved by passing the air through two (2) sequential filters $(20 \mathrm{~cm}$ in thickness) of HENAZE (grain size 8-25 mm). The addition of HENAZE in mortar mixtures of sand and portland cement leads to a decrease of up to $18 \%$ unit weight. The increase of the HENAZE proportions increases 
the porosity and water absorption of the lighter mortar and at the same time, decreases the uniaxial compressive strength (Vogiatzis et al., 2012).

\section{Discussion and Conclusions}

Only clinoptilolite of sedimentary origin (clinoptilolitic zeolitic tuffs) with $\geq 80 \mathrm{wt} \%$ clinoptilolite, $\leq 20 \mathrm{wt} \%$ clay minerals, free of fibres and quartz, can be used (in powder form) as feed additive for all animal species (EU Regulation No 651/2013) and consequently as nutrition supplement for humans. In humans and animals, inhaled or injected or swallowed, fibrous zeolites (mainly erionite and mordenite, and to a lesser extent roggianite and mazzite), as well as the $\mathrm{SiO}_{2}$ minerals (quartz, cristobalite, tridymite), are toxic, carcinogenic and highly pathogenic (e.g., Davis, 1993; Driscoll, 1993; Saffiotti et al., 1993). The Hellenic Natural Zeolite (HENAZE) on average, contains $89 \mathrm{wt} \%$ clinoptilolite, $<3 \mathrm{wt} \%$ clay minerals, is free of fibres (fibrous zeolites), but unfortunately is not free of quartz. Mineralogically, HENAZE do not meet the requirements of the EU Regulation No 651/2013, and thus cannot be used as feed additive for all animal species and consequently as nutrition supplement, since it contains $3 \mathrm{wt} \%$ quartz and $2 \mathrm{wt} \%$ cristobalite \pm tridymite. Chemically, the HENAZE is suitable for use as soil conditioner, since the concentration of trace elements $(\mathrm{Cd}$, $\mathrm{Cr}, \mathrm{Cu}, \mathrm{Hg}, \mathrm{Ni}, \mathrm{Pb}, \mathrm{Zn}$ ) are lower than the maximum allowable concentrations in agricultural soils (EU Directive 278/EEC 1986). The HENAZE is of very high quality clinoptilolitic zeolitic tuff. The sorption and fixation of the different components from their solutions by the micro/nano-pores of clinoptilolite, as well as the meso- and macro-pores of the HENAZE, is attributed to absorption (ion exchange), adsorption and surface precipitation processes. The clinoptilolite, because of the existence in its structure, of the Brønsted acidic active sites and the Lewis basic active sites, reacts with the positively or/and negatively charged chemical components, even with molecules in gas condition. These chemical processes are related to sorption and fixation physicochemical phenomena of ions and molecules, and concerns both the structural void spaces (micro/nano-pores) and the surface of the clinoptilolite crystals, consequently the meso- and macro-pores of the HENAZE. The HENAZE shows an ability to neutralize the $\mathrm{pH}$ of acidic and basic waters, acting either as a proton acceptor or donor, exhibiting thus an amphoteric character (Misaelides et al., 1995; Godelitsas et al., 2003; Filippidis and Kantiranis, 2007; Filippidis, 2010a, 2013).

Considering among others, EU Regulation No 651/2013, EU Directives 278/EEC 1986 and 98/83/EC/1998, the high toxicity in animals and humans of fibrous zeolites and crystalline silica (e.g., Davis, 1993; Driscoll, 1993; Saffiotti et al., 1993), the pozzolanic activity of minerals, the bioavailability of elements, the trace elements and radionuclides (radioactivity) of zeolitic tuffs, the observed negative-zero performance in greenhouse crops (lettuce and peppers), in the field (maize), in the removal of metals from wastewater and drinking water, due to the addition of low quality zeolitic tuff (40\% clinoptilolite) (Gkertsis, 2008; Marantos and Angelatou, 2009), the low quality zeolitic rock (70\% clinoptilolite) proved to be insufficient for nitrate retention (Mazeikiene et al., 2008) and the performance-yield and the cost in all type of uses, it is very important to emphasize the quality characteristics of the zeolitic tuffs, in relation to different uses. The specifications for the various uses of HEU-type (clinoptilolite-heulandite) zeolitic tuffs are:

( $\mathbf{1}^{\text {st }) ~ T h e ~ z e o l i t i c ~ t u f f, ~ f o r ~ a l l ~ u s e s, ~ m u s t ~ b e ~ f r e e ~ o f ~ f i b r e s ~(E U ~ R e g u l a t i o n ~ N o ~ 651 / 2013) ~ a n d ~}$ consequently fibrous zeolites and other fibrous minerals (tiny needles). The presence of fibrous zeolites (e.g., erionite, mordenite, roggianite, mazzite) is inhibitory for the use of zeolitic tuffs, $\left(\mathbf{2}^{\text {nd }}\right)$ The zeolitic tuff must be free of quartz for use (in powder form) as feed additive for all animal species (EU Regulation No 651/2013). The zeolitic tuff must be free of quartz, cristobalite and tridymite (crystalline $\mathrm{SiO}_{2}$-phases, tiny insoluble axes) for use as feed additive for all animal species and consequently for humans as nutrition supplement. The same applies to the use as livestock floor materials, in case the animals are used to consume materials from the floor, $\left(3^{\text {rd }}\right)$ The content of the HEU-type zeolite (clinoptilolite-heulandite) in the zeolitic tuff, for all uses, should be $\geq 80 \mathrm{wt} \%,\left(4^{\text {th }}\right)$ The content of the clay minerals in the zeolitic tuff, should be $\leq 20 \mathrm{wt} \%$. Particular care is required (zero or very low content) for the swelling clay minerals (high pozzolanic activity, equivalent in 
action to the cement), $\left(5^{\text {th }}\right)$ The zeolitic tuff should not be burdened or contaminated with major elements, trace elements and radionuclides (radioactivity) and their concentrations should not exceed the Maximum Allowable Concentrations (MAC) of trace elements in agricultural soils, according to the World, European and Greek legislation, and also should not be enriched compared to the average values of the rocks and the Earth's crust, $\left(6^{\text {th }}\right)$ The bioavailability and leachability of dangerous-harmful metals, trace elements, radionuclides and chemical compounds of the zeolitic tuff, should be zero or extremely low. The metals, trace elements and radionuclides should be located within the crystal structure of the zeolite (absorption) rather than the surface of the zeolite crystals (adsorption, surface precipitation), $\left(\mathbf{7}^{\text {th }}\right)$ The main exchangeable cations of the HEU-type zeolite (clinoptilolite-heulandite) contained in the zeolitic tuff, should be $\mathrm{K}, \mathrm{Ca}, \mathrm{Mg}$ and $\mathrm{Na},\left(\mathbf{8}^{\text {th }}\right)$ The sorption-uptake ability (ion exchange capacity) of the zeolitic tuff, should be $>170 \mathrm{meq} / 100 \mathrm{~g},\left(\mathbf{9}^{\text {th }}\right)$ The granulation of the zeolitic tuff for different uses, should consider the size of the shards and the type of application and $\left(\mathbf{1 0}^{\text {th }}\right)$ The Correlation of the cost, the economic and environmental benefits, always should seriously be considered.

The great majority (>99\%) of zeolitic tuffs are unsuitable and/or dangerous for consumption from animals and humans. Even if the zeolitic tuffs fulfill all the above mineralogical, chemical, morphological and radiological conditions, particular care is needed for those who take medicines, because the zeolitic tuffs as a material with high adsorption capacity, can bind, inactivate and remove the beneficial medicine from the human body, with consequent harm.

\section{Acknowledgments}

Thanks to GEO-VET N. Alexandridis \& Co O.E. for the supply of the HENAZE samples.

\section{References}

Davis, J.M.G., 1993. In vivo assays to evaluate the pathogenic effects of minerals in rodents. In: Health Effects of Mineral Dusts. MSA, Washington DC, Reviews in Miner., 28, 471-487.

Driscoll, K.E., 1993. In vitro evaluation of mineral cytotoxicity and inflammatory activity. In: Health Effects of Mineral Dusts. MSA, Washington DC, Reviews in Miner., 28, 489-511.

EU Directive 278/1986. Council Directive 86/278/EEC of 12 June 1986 on the protection of the environment, and in particular of the soil, when sewage sludge is used in agriculture.

EU Directive 83/1998. Council Directive 98/83/EC of 3 November 1998 on the quality of water intended for human consumption.

EU Regulation No 651/2013. Commission Implementing Regulation (EU) No 651/2013 of 9 July 2013 concerning the authorisation of clinoptilolite of sedimentary origin as a feed additive for all animal species and amending Regulation (EC) No 1810/2005.

Filippidis, A., 2005. Study: Mineralogy and physico-chemical characteristics of five natural zeolite samples on behalf of N. Alexandridis \& Co OE (in Greek), Thessaloniki, $10 \mathrm{pp}$.

Filippidis, A., 2007. Zeolites of Trigono Municipality of Evros Prefecture in industrial, agricultural, cattle-raising and environmental technology (in Greek), Proc. of the Sci. Meet. Develop. Perspectives of Northern Evros, Petrota, 4 August, 89-107.

Filippidis, A., 2008. Treatment and recycling of municipal and industrial waste waters using Hellenic Natural Zeolite: A Review. Proc. of the AQUA $3^{\text {rd }}$ Int. Conf. Athens, 16-19 Oct., 5 pp.

Filippidis, A., 2009. Management of urban and industrial wastewaters using Hellenic Natural Zeolite. Review article (in Greek with English abs), Proc. of the Congr. Integrated Manag. Water Resources, Volos, 27-30 May, II, 829-836.

Filippidis, A., 2010a. Environmental, industrial and agricultural applications of Hellenic Natural Zeolite, Hellenic Journal of Geosciences, 45, 91-100.

Filippidis, A., 2010b. Purification of municipal wastewaters and production of odorless and cohesive zeosewage sludge, using Hellenic Natural Zeolite, Sci. Annals, Geology, AUTh, 100, 55-62, 2010. 
Filippidis, A., 2013. Industrial and municipal wastewater treatment by zeolitic tuff, Water Today, Jan., V/X, 34-38.

Filippidis, A. and Kantiranis, N., 2002. Study: Morphology, mineralogy, chemistry, mineralchemistry and ion exchange capacity of five natural zeolite samples on behalf of $\mathrm{N}$. Alexandridis \& Co OE (in Greek), Thessaloniki, Greece, 5 pp.

Filippidis, A. and Kantiranis, N., 2007. Experimental neutralization of lake and stream waters from N. Greece using domestic HEU-type rich natural zeolitic material, Desalination, 213, 47-55.

Filippidis, A. and Tsirambides, A., 2012. Quality characteristics of the Greek zeolites, environmental, industrial, agricultural and aquacultural uses of Hellenic natural zeolite: A review (in Greek with English abs), Sci. Annals, Geology, AUTh, 101, 125-133.

Filippidis, A., Kantiranis, N., Drakoulis, A. and Vogiatzis, D., 2006. Improvement and protection of the lake Koronia using natural zeolite (in Greek with English abs), Proc. of the $2^{\text {nd }}$ Congr. Aristotle Univ. Envir. Council, Thessaloniki, 1-4 June, 273-279.

Filippidis, A., Siomos, A., Barbayiannis, N. and Filippidis, S., 2007. Agricultural and environmental applications using Hellenic Natural Zeolite of Petrota (Evros) (In Greek with English abs), Proc. of the Jean Monnet Congr., Veria, 30 November - 1 December, 557-569.

Filippidis, A., Apostolidis, N., Filippidis, S. and Paragios, I., 2008a. Purification of industrial and urban wastewaters, production of odorless and cohesive zeo-sewage sludge using Hellenic Natural Zeolite, Proc. of the $2^{\text {nd }}$ Int. Conf. Wastewater Treat. Plants, Skiathos, 2-4 May, 403-408.

Filippidis, A., Apostolidis, N., Filippidis, S. and Paragios, I., 2008b. Purification of urban wastewaters, production of odorless and cohesive zeo-sewage sludge using Hellenic Natural Zeolite (in Greek with English abs), Proc. of the ${ }^{\text {th }}$ Int. Hydrogeol. Congr. Athens, 7-10 October, 2, 789-798.

Filippidis, A., Apostolidis, N., Paragios, I. and Filippidis, S., 2008c. Zeolites clean up, Industrial Minerals, 485 (April), 68-71.

Filippidis, A., Apostolidis, N., Paragios, I. and Filippidis, S., 2008d. Purification of dye-work and urban wastewaters, production of odorless and cohesive zeo-sewage sludge, using Hellenic Natural Zeolite, Proc. of the $1^{\text {st }}$ Int. Conf. Hazardous Waste Manag., Chania, 1-3 October, 8 pp.

Filippidis, A., Apostolidis, N., Paragios, I. and Filippidis, S., 2008e. Safe management of sewage sludge, produced by treatment of municipal sewage with Hellenic Natural Zeolite, Proc. of the AQUA $3^{\text {rd }}$ Int. Conf. Athens, 16-19 October, 5 pp.

Filippidis, A., Apostolidis, N., Paragios, I. and Filippidis, S., 2008f. Production of odorless sewage sludge, purification of dye-work and urban waste-waters, using Hellenic Natural Zeolite (in Greek with English abs), Proc. of the $3^{\text {rd }}$ Macedonia Envir. Congr., Thessaloniki, 14-17 March, 8pp.

Filippidis, A., Apostolidis, N., Paragios, I. and Filippidis, S., 2008g. Purification of dye-work wastewaters and production of cohesive zeo-sludge using Hellenic Natural Zeolite (in Greek with English abs), Proc. of the $8^{\text {th }}$ Int. Hydrogeol. Congr., Athens, 7-10 October, 2, 783-788.

Filippidis, A., Apostolidis, N., Filippidis, S. and Paragios, I., 2009a. Purification of sewage effluents and production of odourless-cohesive sewage sludge, using Hellenic Natural Zeolite (in Greek with English abs), Honorary to Prof. Tzimopoulos, YDROGAIA, 425-434.

Filippidis, A., Papastergios, G., Apostolidis, N., Paragios, I., Filippidis, S. and Sikalidis, C., 2009b. Oderless and cohesive zeo-sewage sludge produced by Hellenic Natural Zeolite treatment, Proc. of the $3^{\text {rd }}$ AMIREG Int. Conf. Athens 7-9 September, 96-100.

Filippidis, A., Moustaka-Gouni, M., Papastergios, G., Katsiapi, M., Kantiranis, N., Karamitsou, V., Vogiatzis, D. and Filippidis, S., 2010a. Cyanobacteria removal by Hellenic Natural Zeolite. Proc. of the $3^{\text {rd }}$ Int. Conf. Wastewater Treat. Plants, Skiathos, 14-16 May, 383-387.

Filippidis, A., Papastergios, G., Apostolidis, N., Filippidis, S., Paragios, I. and Sikalidis, C., 2010b. Purification of urban wastewaters by Hellenic Natural Zeolite, Bull. Geol. Soc. Greece, 43(5), 2597-2605.

Filippidis, A., Moustaka-Gouni, M., Katsiapi, M. and Filippidis, S., 2011a. Cyanobacteria removal by Hellenic Natural Zeolite (in Greek with English abs), Proc. of the $4^{\text {th }}$ Macedonia Envir. Conf., Thessaloniki, 18-20 March, 9 pp. 
Filippidis, A., Tsirambides, A., Kantiranis, N., Tzamos, E., Vogiatzis, D., Papastergios, G., Papadopoulos, A. and Filippidis, S., 2011b. Purification of wastewater from Sindos industrial area of Thessaloniki (N. Greece) using Hellenic Natural Zeolite. Environ, Earth Sci., Springer, Berlin, Advances in the Research of Aquatic Environment, 2, 435-442.

Filippidis, A., Tsirambides, A., Tzamos, E., Vogiatzis, D., Papastergios, G., Georgiadis, I., Papadopoulos, A. and Filippidis, S., 2011c. Purification of wastewater from Thessaloniki industrial area using Hellenic natural zeolite (in Greek with English abs), Proc. of the $21^{\text {st }}$ Panhel. Chem. Congr., Thessaloniki, 9-12 Dec., 8 pp.

Filippidis, A., Kantiranis, N., Vogiatzis, D., Tzamos, E., Papastergios, G. and Filippidis, S., 2012. Odourless-cohesive zeosewage sludge production and urban wastewater purification by natural zeolite, Proc. of the XI Int. Conf. Prot. Restor. Enviv, Thessaloniki, 3-6 July, 582-588.

Filippidis, A., Godelitsas, A., Kantiranis, N., Gamaletsos, P., Tzamos, E. and Filippidis, S., 2013. Neutralization of sludge and purification of wastewater from Sindos industrial area of Thessaloniki (Greece) using natural zeolite, Bull. Geol. Soc. Greece, 47(2), 920-926.

Filippidis, A., Kantiranis, N., Tziritis, E., Tzamos, E., Vogiatzis, D. and Filippidis, S., 2014. The use of Hellenic Natural Zeolite (HENAZE) in the purification of Thessaloniki industrial area wastewaters, Proc. of the 10 Intern. Hydrogeol. Congr., Thessaloniki, 8-10 Oct., 187-193.

Filippidis, A., Kantiranis, N., Papastergios, G. and Filippidis, S. 2015a. Safe management of municipal wastewater and sludge by fixation of pollutants in very high quality HEU-type zeolitic tuff, Journal of Basic and Applied Research International, 7(1), 1-8.

Filippidis, A., Papastergios, G., Kantiranis, N. and Filippidis, S., 2015b. Neutralization of dyeing industry wastewater and sludge by fixation of pollutants in very high quality HEU-type zeolitic tuff, Journal of Global Ecology and Environment, 2(4), 221-226.

Filippidis, A., Tziritis, E., Kantiranis, N., Tzamos, E., Gamaletsos, P., Papastergios, G. and Filippidis, S., 2015c. Application of Hellenic Natural Zeolite in Thessaloniki industrial area wastewater treatment, Desalination and Water Treatment, doi: 10.1080/19443994.1103314.

Gkertsis, A.K., 2008. Evaluation of zeolitic tuffs, vermiculite and wet fly ash as soil conditioners (in Greek), IGME Final Report, Athens, 75 pp.

Godelitsas, A., Charistos, D., Tsipis, C., Misaelides, P., Filippidis, A. and Schindler, M., 2003. Heterostructures patterned on aluminosilicate microporous substrates: Crystallisation of cobalt (III) tris(N,N-diethyl-dithiocarbamato) on the surface of HEU-type zeolite, Microp. \& Mesop. Mat., 61, 69-77.

Marantos, I. and Aggelatou, V., 2009. Evaluation of natural zeolites to improve the quality of drinking water, the sorption of heavy metals from wastewaters and the quality improvement of soils (in Greek), IGME Final Report, Athens, 21 pp.

Mazeikiene, A., Valentukeviciene, M., Rimeika, M., Matuzevicius, A.B. and Dauknys, R., 2008. Removal of nitrates and ammonium ions from water using natural sorbent zeolite (clinoptilolite), J. Envir. Eng. Landsc. Manag., 16, 38-44.

Misaelides, P., Godelitsas, A., Filippidis, A., Charistos, D. and Anousis, I., 1995. Thorium and uranium uptake by natural zeolitic materials, Sci. Total Environment, 173/174, 237-246.

Saffiotti U., Daniel L.N., Mao Y., Williams O., Kaighn M.E., Ahmed N. and Knapton A.D., 1993. Biological studies on the carcinogenic mechanisms of quartz. In: Health Effects of Mineral Dusts. MSA, Washington DC, Reviews in Miner. 28, 522-544.

Vogiatzis, D., Kantiranis, N., Filippidis, A., Tzamos, E. and Sikalidis, C., 2012. Hellenic Natural Zeolite as a replacement of sand in mortar: Mineralogy monitoring and evaluation of its influence on mechanical properties, Geosciences, 2, 298-307. 